\title{
Nurturing Creativity and Innovation in African Enterprises: A Case Study on Kenya
}

\author{
Bitange Ndemo and Dennis Aiko \\ Additional information is available at the end of the chapter \\ http://dx.doi.org/10.5772/65454
}

\begin{abstract}
Innovation and creativity are the backbone of entrepreneurship. Domestic and international competition, changing government regulations and rapidly shifting market conditions demand constant creative innovation for corporations to survive. Despite an increase in the number of innovations from African enterprises and research institutions in the current digital age, there is a lack of investment in innovation and creativity to ensure the sustainability of the continent's enterprises. This chapter seeks to address the problem of how to support innovation and creativity in African enterprises by combining two theories of diffusion of innovation and product life cycle through examples from Kenya. Existing research on innovation and creativity tends to focus on the diffusion of technologies on the continent but fails to question the role of the mindset of entrepreneurs, the role of the individual, and the current trajectory of innovation in Africa as it pertains to the industrial revolutions elsewhere in the world. This chapter focuses on local expressions of innovation or the relationships that exist between their different components. Consequently, it aims to provide an overview of how innovation and creativity can be locally supported as a strategy for building durable and profitable enterprises in Africa.
\end{abstract}

Keywords: innovation, creativity, entrepreneurship

\section{Introduction}

Innovation and creativity are the backbone of enterprise development, a reality that is beginning to be absorbed by the African business community. Domestic and international competition, changing government regulations and rapidly shifting market conditions demand constant creative innovation for corporations to stay afloat. On a wider perspective, it is assumed that a combination of innovation and creativity offers solutions to critical socialpolitical challenges such as security, energy, public health, food and water supply, climate stability and poverty. Although many internal corporate innovations in many parts of the 
world have dedicated research and development $(R \& D)$ units, very few African organizations do. What are common on the continent, however, are product development units, market research units, and sales and market development units.

Promoting technological innovation and its diffusion in Africa remains a farfetched dream. Innovation climates in African countries are, by nature, problematic, characterized by poor business and governance conditions, low educational levels and mediocre infrastructure. Many studies (see e.g. [1, 2]) make the compelling case that in order to survive and be productive, corporations must be innovative [3]. Rogers's [4] theory of innovation diffusion explains how, why and at what rate new ideas and technology spread and is often used by creative corporations to know when to change gears or adapt to a new set of conditions. Most products go through different stages of innovation diffusion that mirror Vernon's [5] concept of product life cycle. These two theories will be explained in more detail below to argue that in order for African businesses to compete globally, much more investment is required in R\&D.

\section{Background}

This chapter explores the conceptualization of new ideas and how they are implemented within African enterprises. Specifically, it focuses on how enterprises regenerate themselves when products reach maturity. It addresses the following questions: where do new products come from? What decision mechanisms lead to new product development? What necessitates change? What is the contribution of the local knowledge? And, how do African organizations respond to competition?

The chapter aims to show why African businesses will need to invest considerably more resources in R\&D and focus on building local content in order to increase their competitiveness in the global market place. Sustainable development cannot be assured with abundant resources alone but requires the capacity to convert available resources into new value-added products. The role of policy, participation of institutions of higher learning and industry all play key roles in the realization of this concept on the continent. The study's recommendations point to the gaps that exist in literature on how best to realize creativity and innovation for sustainable business development.

\section{Creativity and innovation}

Aubert [6] noted that the promotion of innovation in developing countries will soon became a fashionable subject. It is for this reason that throughout the 2000s many African countries developed elaborate plans through their so-called 'vision documents' or long-term development plans to position themselves as key players in the world's fourth industrial revolution (explained in more detail in the following section). For each country to play a role in industrialization, creativity and innovation at firm level is central to their strategy. However, Baucus et al. [7] argue that firms face numerous challenges and operate within highly competitive environments in the global economy. Notable challenges include, but are not limited to, lack of speed and flexibility required responding to markets demands [8], lack of operational 
efficiency to affecting business costs, environmental challenges, diverse workforce management issues and the absence of good working relationships with key stakeholders [9].

The challenge to Africa's policymakers and the academia is therefore how to best respond to the concerns above and assist in the creation of sustainable businesses. In reference to various researchers, Baucus et al. [7] notes how academics have responded to many of these competitive challenges by advocating creativity as a solution, whether realized through a learning organization [10, 11], an innovative firm [12] or simply a creative company [13]. Globally competitive firms commonly empower employees to use their own creativity and judgement [14]. At the organizational level, there is increasing recognition that they must engage in ongoing processes of experimentation, rethinking of their design and operations to solve problems creatively and add value [15].

The African organization will have to do more than what research from elsewhere has done. Ndemo [16] elaborated how the change of mindset was necessary to introduce creativity and innovation to the Kenyan Civil Service. In building a new creativity and innovation model, this chapter will draw from firm-level qualitative interviews and the author's experience gained in the transformation of the Information and Communications Ministry of the Government of Kenya as well other organizations in Africa.

\section{The African enterprise}

The history of African enterprise starts largely with Micro-Small and Medium Enterprises (MSMEs) as well as privatized state-owned enterprises (SOEs). McCormick [17] noted that development in Africa was most strongly tied to small-scale industry or industrialization itself. Most of the large African enterprises in existence today were at one point SOEs that after many years of poor performance were transformed under recommendation from the Bretton Woods Institutions to become private enterprises. Nellis [18] argued 'By the mid-1990s, however, the idea of making SOEs function efficiently and effectively under government management was largely abandoned by the International Financial Institutions (IFIs) and privatization and private participation became the order of the day'.

Some African governments are beginning to embrace innovation and R\&D support. In Kenya, for example, Ndemo [19] noted that in the past decade, Kenya has made unprecedented progress in innovation and creativity, one in which the youth have played important innovative roles. The government on their part has shown clear appreciation of innovation and the desire to support the youth in being the drivers of business innovation. This was manifested in a number of government policies and the increased funding going towards research and development as a strategy for creating more jobs for the youth and more so for those involved in innovation.

\section{The study problem}

A number of African countries have invested in public research and development organizations but in the majority of cases these organizations are not linked to private enterprise or the 
country's SOEs. In Kenya, for example, the links between the Kenya Industrial Research and Development, the Kenya Agricultural and Livestock Research Organization and several other sectoral research institutions to industry have been minimal to date. Academic institutions involved in research activities too have minimal links to private enterprise. The lack of a locally structured R\&D to assist both the MSMEs and large enterprises has undermined the regeneration of enterprise on the continent. Because their enterprises are largely replication of what exists, most of these MSMEs do not live beyond 5 years. This is largely because they have neither the capacity nor the capability to finance their own R\&D activities. The end result is that many MSME's competitiveness is compromised in a rapidly changing world. The Achilles' heel to Africa's growth is thus how the continent can build local R\&D capability and simultaneously, the capacity to nurture the mindset to enhance creativity and innovation to sustain entrepreneurial development and economic growth.

\section{The history of industrial revolutions and innovation}

The world's industrial revolutions are some of the most celebrated watersheds in human history [20]. The first industrial revolution, which took place between 1800 and 1899, ushered in machine automation impacting positively on the construction of bridges, roads and railway lines. The second industrial revolution came about as a result of machine automation leading to mass production with high efficiencies. The second industrial revolution was characterized by productive connectivity through road and railway networks as well as the specialization of the labour force. The third industrial revolution was propelled by the rise of the digital age, of more sophisticated automation and by increasing connectivity between and within humanity and the natural world. And finally, the fourth industrial revolution is being driven by extreme automation and connectivity. A future feature of the fourth (and coming) industrial revolution will be the wider implementation of artificial intelligence (AI).

These earlier industrial revolutions have been thought of by some as essentially consisting of the arrival of the first of what have been called general purpose technologies, propelled by technological innovations [21]. General purpose technologies refer to innovations that have been applied pervasively throughout the economy, that go through prolonged periods of improvement and that spawn further innovation in the sectors they are employed in. Following this logic, it is clear that innovation is the central driving force behind the industrial revolutions.

\subsection{First industrial revolution and innovation}

The first industrial revolution is often viewed as the beginning of modern economic growth in Europe. Mokyr [22] observed that in Britain, more than anywhere else, technological innovation was largely confined to the private sector, with the state remaining in the background and only playing a more interventionist role sporadically. Supporting Mokyr's assertions, Berg [21] noted that the pivotal individuals who facilitated the innovation process in Britain were entrepreneurs. 
The industrial revolution was fundamentally a technological revolution, and progress in understanding it can be made by focusing on the sources of invention and innovation [22]. While Mokyr elucidates this theory by focusing on the context in which invention took place and the essence of information flows, our understanding of the industrial revolution can be enhanced by paying more attention to the perceived incentives to the entrepreneurs and the context in which they worked. Using this approach, Crafts [23] concluded that the reason the industrial revolution happened in Britain in the eighteenth and nineteenth centuries was not because of luck or British genius but it was Britain's success in the international economy that set in motion the economic developments that presented Britain's entrepreneurs with unique and highly remunerative possibilities. The industrial revolution was thus an innovative response to an opportunity.

Scholars have argued that product innovations were a sole cause of the industrial revolution [21]. Trade with other countries introduced new products to Britain such as cotton fabrics, porcelain, coffee and tea. Equipped with a variety of new products, Britain's market attracted more entrepreneurs and business people. This had a huge impact on the demand for labour resulting in high wages, which meant that the demand for these goods was not confined to the middle classes but included skilled workers and even labourers. The British market was far more inclusive than in much of Europe. British manufacturers on their part attempted to manufacture these products or imitations of them in order to meet growing demand. At the same time, there was also much product innovation going on. Manufacturers developed materials, products and designs that could effectively compete with the international products [24]. While some scholars view the industrial revolution as an exercise in import substitution, others think that process innovations were important in their own [25].

Whilst the first industrial revolution was taking place in Britain, Africa and the rest of the world were inactive. There is paucity of accounts and historical records about the economic and innovation activities taking place. As Allen [20] succinctly argued, the African cultural practices and value systems, unlike the European ones, were inhibitive to and incompatible to innovative technology.

\subsection{Second industrial revolution and innovation}

Baumol [26] differentiated the second industrial revolution from the first industrial revolution on the basis of three factors namely higher levels of automation via the development of mass production, efficient connectivity in production through the division and specialization of labour force, and progress in the use of electricity and petroleum sources of energy.

In the same vein, Baumol [26] argued that while at first the second industrial revolution was limited to internal organizational supply chains, automation and connectivity provided firm grounds for supply chains to evolve and grow into the complex systems as we know them today. Notably, the supply chains rapidly grew and expanded across different industries. Equally, automation extended to the agricultural sector boosting agricultural yields through massive industrial fertilizer production, thus resulting in the introduction of industrial food storage methods via refrigeration. 
Standardization was one of drivers of the achievements of the second industrial revolution. Standards were introduced in product quality and in transportation systems. Legal and trade protections were also needed to assure innovators that they would be able to enjoy the financial rewards of their creativity, without being exposed to early competition from rivals copying their technologies.

\subsection{Third industrial revolution}

The rise of the digital age characterized the third industrial revolution [27]. The third industrial revolution is largely associated with massive connectivity which began in 1969 when the first message was sent over ARPANET, an equivalent of today's Internet. Berg [21] posted that the scope for automation was greatly enhanced by the postulations of Moore's law, which observed that the number of transistors on an integrated circuit doubled approximately every 2 years. These rapid changes in automation coupled with the growing appreciation of the environmental deterioration caused poor farming methods raised concerns resulting in the rise of a green revolution [21].

Moore's law was all about electronic circuitry, which was the foundational technology during the third industrial revolution. The law as it was commonly referred to captured the wider phenomenon of output growing as an exponential function of input. In this sense, Moore's law suggested that greater computing power had the ability to automate more complex tasks.

\subsection{Fourth industrial revolution}

In his model, Mokyr [29] observes that the fourth industrial revolution is characterized by both extreme automation and extreme connectivity. Extreme automation will expand the range of jobs ranging from highly repetitive low-skill jobs to highly routine medium-skill jobs. He further asserts that artificial intelligence will be expected to be a pervasive feature of the fourth industrial revolution. Extreme automation via AI will increasingly automate some of the skills that formerly only humans possessed. In the same spirit, Baumol (2007) contends that AI is poised to make the greatest gains in large data processing, having the potential to include processing language and images, which have far been off-limits for computers to understand for a long time. Extreme automation has the ability to allow for more robots and AI to produce more outputs, quickly analyse results, make complex repetitive decisions and provide conclusions.

On the flip side, Berg [21] argues that a great number of industries will likely be disrupted by the advances associated with the fourth industrial revolution. Entrepreneurs will most likely be tempted to pursue disruptive trends by investing in the beneficiaries of extreme automation and connectivity, including robotics technologies, artificial intelligence and in social media firms.

Large data are arguably the result of both extreme automation and extreme connectivity. Mokyr [29] argues that large data are a "child" of the fourth industrial revolution. Large data provide a good example of how extreme connectivity is going to give rise to new business models and expanding economic supply in ways previously thought impossible. Key among 
the most prominent potential beneficiaries of the fourth industrial revolution are organizations that are able to harness large data, provide effective data analysis and promise protection from the threat of cyber crime.

\section{Evolution of African indigenous innovation and technology}

The evolution of innovation and technology everywhere in the world including Africa is an age-old phenomenon. Innovation is scientific knowledge that is put to practical ends. This knowledge is in then used in turn to design machinery, materials and industrial processes, generally known as engineering.

\subsection{Pre-colonial innovation in Africa}

African innovations and technology such as western innovation and technology have unfolded since the dawn of human history [27]. This is evidenced by the presence of tools used by African ancestors interred in valleys across Sub-Saharan Africa. Africa before colonialism was not economically isolated from the rest of the world. Many African states were actively engaged in some form of innovative international trade. As far back as the time of the pharaohs of ancient Egypt, West Africa had developed extensive international trading systems. This is evidenced during the eras of Ghana, Mali and Songhai empires extensively captured in the ancient history of Africa. These empires relied heavily on the taxing of foreign trade to finance their government expenditures. The wealth derived from the international trade was used in the administration of their kingdoms and to some extent maintenance of trade routes that criss-crossed the African ragged terrain.

Prior to the colonial period, Africa practiced indigenous innovation and technology expressed in the local systems [30]. Remarkable technological innovations were made by Africans in traditional iron melting, wood curving and ivory working as well as in simple cloth weaving, pottery and indigenous medicinal and herbal development. Most of the innovative techniques involved in these processes were, however, either disoriented or discontinued but were, at the time, environmental friendly and acceptable within the cultural value system of the people [30]. African technology emphasized on the quality of life as measure in human, cultural and spiritual terms as opposed to purely material terms. Its primary objective was to equip everyone with the knowledge of how all essential tasks of life are carried out. In this regard, Andah (1992) contends that everybody was instilled and equipped with a feeling of self-respect and belonging borne out of confidence. But this confidence came to an abrupt end as it was eroded by the invasion of European religion and new forms of modernization.

Mokyr [22] acknowledges the fact that before Africans came in contact with Europe in the fifteenth century, African technological systems may have been underdeveloped. This underdevelopment provided firm grounds for exploitation of the African continent and her resources for the benefit of the outsiders (Arabs and Europeans). The African resource exploitation was first unleashed with the commencement of slave trade, where Arabs and Europeans legitimized the trade. This was followed by the scramble and partitioning of Africa giving rise 
to colonization and neocolonialism. European colonization and imperialism fuelled the decay of African technological and innovation development. This dealt a deadly blow to the African innovation and technology and offers an explanation to the decline of African technological development [28].

After independence, successive governments in Africa embraced foreign-imported technology at expense of the indigenous technology. This discouraged the development of the indigenous technology greatly. Foreign-imported products found their way into the local market stifling out any meaningful innovative production locally. The tendency towards the establishment of wholesomely imported technology commonly referred to as technology transfer has been, sadly, a dream of most African states. On the part of Africans, the general feeling of inferiority generated by this massive importation syndrome has given rise to negative ideas about products of indigenous technology and innovation, while foreign products are seen as superior. At the extreme and as sad as it may sound, Africans prefer imported second-hand garments to new locally manufactured garments. As rightly argued by Mokyr [22], all these factors have had adverse effects on the development of African innovation and creativity.

\subsection{Innovation in Africa after independence}

After independence, the colonial legacies and the reasons for which Africa agitated for self-rule were still rife. Various ideological thinking and postulations were available on sale and buy basis. Socialism and capitalism ideologies made inroads to African leaders promising to help in state building and economic development. These, among a combination of other factors, propelled the development of innovation and creativity on the continent.

A brief overview of the African economic picture reveals a paradox where the continent that has rich mineral resources, nearly a billion people and a land mass larger than the size of China, USA, India and Western Europe, Argentina combined but still dependent on foreign aid from donors. This occurs despite the huge endowments of resources on the continent, both known and yet to be known. Backed up by these resources, the African continent should have been a production and innovation centre and not a charity centre of the world where national ownership has been substituted with foreign aid.

Over the years, Africa's levels of innovative productivity have been low and overall competitiveness has remained stagnant for a long period of time. This has been a concern voiced by most African leaders. There is need to address economic development using science and technology backed-up innovations. Few countries in Africa have demonstrated that this is possible. The success of the electronic money transfer mobile phone application called Mpesa in Kenya provides a good example on how innovative technology can be used in economic development.

\section{Theories of change and innovation}

Two key arguments on innovation by Allen [20] that African cultural practices and value systems, unlike the European ones, were inhibitive to and incompatible to innovative technology and Andah (1992) that everybody was instilled with a feeling of self-respect borne out of 
confidence in their own ability to help themselves informed the choice of the theoretical underpinning to this study. Roger's [31] diffusion of innovation theory and Vernon's (1997) concept of product life cycle are used to interrogate if changes brought by industry are enabling creativity and innovation to assess the responsiveness of firms when their products reach maturity.

\subsection{Method}

This study is underpinned by the qualitative case study method of data gathering and analysis with inductive approach. This is consistent with Yin's [32] postulations. Yin posits that the use of qualitative approaches in research studies can help in explaining the ultimate outcomes because the analysis technique consists of matching empirically observed events to theoretically predicted events, which is the interest of this study. In the same spirit, case study research is viewed as an integral approach for studying innovation and creativity. However, its usefulness, relevance and quality will depend on the evaluation situation and the skills of the researcher.

An examination of the literature reveals that creativity and innovation played a key role in the past industrial revolutions. The research for this paper therefore concentrated on 12 manufacturing enterprises in Kenya selected randomly from the Kenya Association of Manufacturers and one service sector firm randomly selected from the Kenya Private Sector Alliance. Qualitative interviews of teams were conducted with senior managers responsible for either operations or strategy in each organization from R\&D and (where applicable) product development, market development and marketing and sales departments to understand their ideation processes and whether or not they led to any form of creativity and innovation. Interviews were conducted using a discussion guide. Although the data were largely collected through interviews, some observations and prior experiences of the authors are drawn upon to explain some of the missing links in the research.

A detailed content analysis of verbatim interview transcripts gave rise to three major themes that cantered on individuals or enablers that nurture creativity and innovation: challenges that undermine creativity and innovation, and opportunities that foster creativity and innovation. These individuals or enablers of creativity and innovation included supportive policies, networks with research institutions and incentives. In challenges of innovation and creativity, the interviews focused on building and retaining R\&D human resource, financing R\&D and safeguarding intellectual property (IP). Lastly in opportunities for creativity and innovation, the focus was on competitiveness, growth and scaling enterprise.

\section{Findings and discussions}

Table 1 shows that virtually all firms that have been in business for more than 20 years had some form of R\&D unit. Firms that have been in business for more than 20 years and had no $R \& D$ unit produced products that rarely face the risk of product life cycle, such as food items whose recipes hardly change with time. All respondents had some form of process innovation in most cases necessitated by new manufacturing equipment from suppliers. Similarly, all 


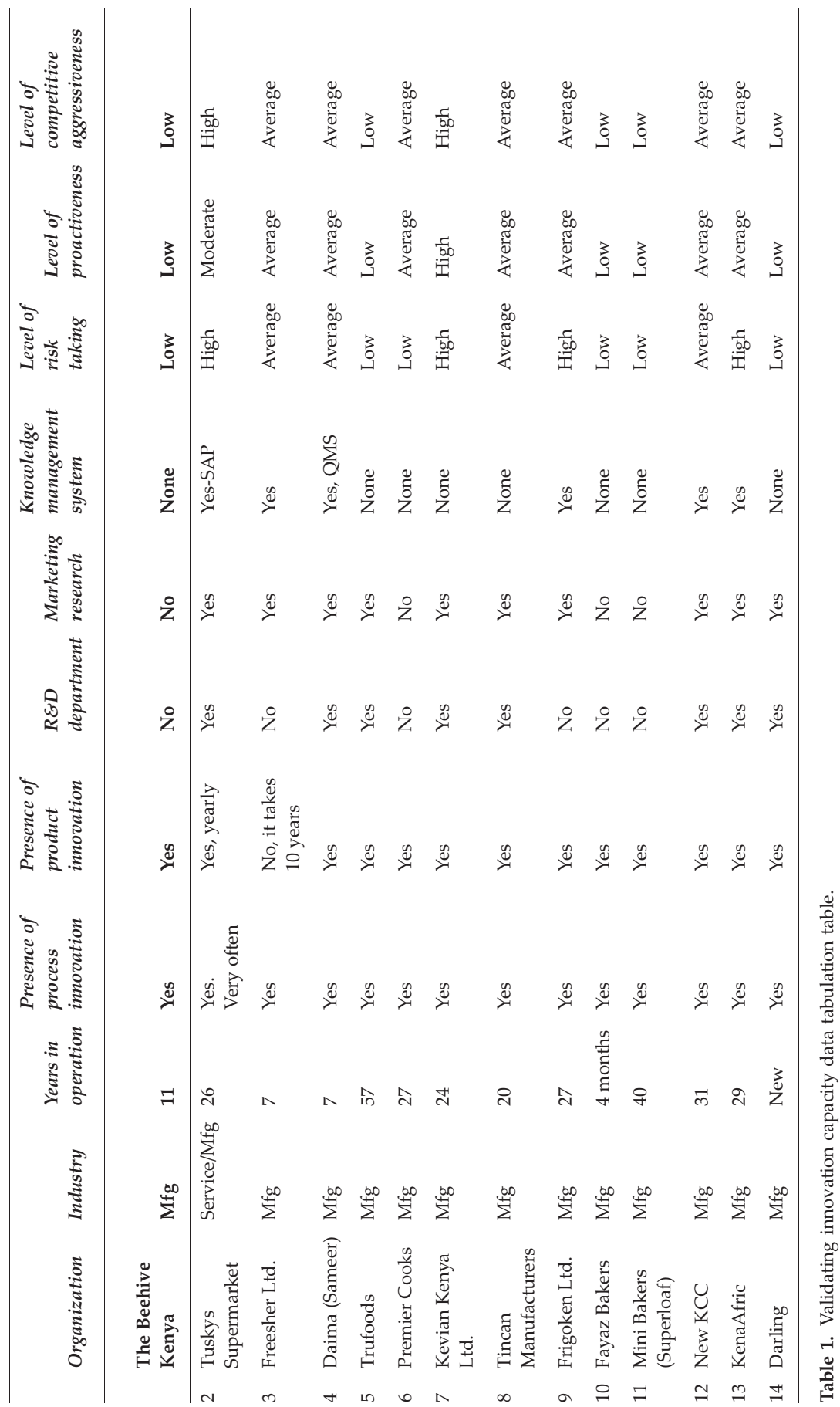


respondents have at some point developed new products and except for three firms, the rest conduct market research on a regular basis sometimes to monitor their market share or customer needs. With respect to knowledge management, most of the corporations that have R\&D units have some form of system such as quality management system (QMS) or SAP's Knowledge Management and Innovation system in place.

Corporations that have been in business for more than 25 years take a higher risk and in terms of proactiveness, and are the only one among high-risk takers that is highly proactive. Only one manufacturing company and the service sector firm seemed aggressive in competitiveness. The entrepreneurial orientation of the service sector firm was extremely high owing to the fact that the competition in the sector is exceedingly high. The competition in the manufacturing sector is not as intense as the service sector. Manufacturing in the dairy sub-sector is moderate and perhaps explains why Kenya Corporative Creameries (KCC) is beginning to invest in R\&D to fight the emerging competition. Table 1 lists organizations that were part of the research.

\section{Emerging issues}

The views of the respondents can be collapsed into four thematic areas: enablers of creativity and innovation, challenges that undermine creativity and innovation, opportunities that foster creativity and innovation, and the missing local contribution to creativity and innovation.

\section{Enablers of creativity and innovation}

The common thread in all the interviews was the role of the state in enabling closer collaboration between research institutions, industry and the state. A significant number of the interviewees were aware of the progress that has been made to bridge the gap between research and industry owing to the fact that policy and institutional frameworks are in place. Since 2006 when Kenya's Vision 2030 was developed, the discourse on innovation intensified and as a result, as Ndemo [19] noted, institutional reforms, human resource development and enhanced R\&D as well as improved science and technology infrastructure were getting to be in advanced stages. An emphasis was also placed on pursuing more and better collaborations and partnerships. The Ministry of Education, Science and Technology was created to spearhead capacity building and innovation.

These initiatives resulted in the development of institutions that support innovation, including but not limited to the Kenya National Innovation Agency, the National Research Fund and the National Commission for Science, Technology and Innovation. The Kenya Education Network is also a key institution within the innovation ecosystem, which facilitates the sharing of educational and research resources through a government-subsidized national broadband network. It also serves as the National Research and Education Network.

Further to strengthen R\&D networks and incentives, a policy on Technology, Science and Innovation Strategy was developed in 2009. Policy seeks to mainstream the application of 
technology, science and innovation in all sectors of the economy to ensure that all Kenyans benefit from all available capacities in order to achieve the objectives of Vision 2030. The policy prioritized several sectors for intervention, including health and life sciences, agriculture and rural development, trade and industry, physical infrastructure, human resource development, natural resource management, energy, environment, and information and communication technologies (ICTs).

As if to address Andah's (1992) concerns of colonial disruption of African institutional and cultural forms, Kenya's 2010 constitution recognized the role of African indigenous innovations in development. This is captured in Article 11, Section $2 b$ and c of the Kenyan constitution, which states: '... recognise the role of science and indigenous technologies in the development of the nation; and promote the intellectual property rights of the people of Kenya'. To support and operationalize the constitutional requirements for the recognition of indigenous innovations, a sessional paper on technology and science was published in 2012, which was followed by an Act of parliament on Science, Technology and Innovation.

\section{Challenges that undermine creativity and innovation}

Although the Kenyan government is spending on human resource capacity development, the greatest concern of virtually all interviewees was the retention of the human resource, financing in-house R\&D and safeguarding their intellectual property. The salary scales in many African countries can rarely sustain good researchers. The competition for quality human resource especially from developed and newly industrialized countries is thus enormous and one that a firm based in Africa cannot win. It is even harder to find enough resources to invest in R\&D. Many of the firms cannot attract external funding of R\&D since the level of technologies they have in place while at the same time global competitors threaten the little market they have. To overcome this problem, business entities must be creative and come up with disruptive products that can scale beyond the local market and attract venture capital to sustainably grow.

Even where there are disruptive products, many believe that danger lurks in safeguarding their intellectual property. Institutions to protect IP are not well developed on the continent. They are slow to review new innovations and respond. Yet, IP is a dynamic and ever-evolving field. Lack of ethics also undermines the trust that organizations need to collaboratively work in research activities. Even more disruptive are the delays in judicial processes in emerging economies caused by business entities under fire for replicating products and branding them as their own. Respondents concluded that for emerging economies to be successful, there is need for reforms across the board, including intellectual property rights.

\section{Opportunities that foster creativity and innovation}

In spite of all the challenges in the Kenyan and African case more generally, the opportunity to become competitive exists. Some of the interviewees have overcome the challenge and are 
effectively competing not just with the local competitors but with international firms too. Their argument especially when competing with multinationals is that they know the terrain and the customer better. This, however, is no excuse for not becoming more creative and innovative. Some do indeed come up with innovative solutions to remain relevant in the market. It is for this reason that some of the firms interviewed have begun to scale up their enterprises into regional markets. None, however, have moved beyond the African market into international markets. The author's experience in the past indeed witnessed products that moved from the local market and scale into the global stage. This was mainly software and applications that quickly attracted international research funding leading to a global product.

As stated earlier, many African firms started as MSMEs and few have climbed the ladder to become large enterprises. Interviewees thought their failure to grow was attributable to lack of finance, market, technology, leadership and poor customer relations but increasingly they have noted that those companies that introduce new products or new ways that respond to customer needs succeed. Tuskyes (one of the firms interviewed), for example, is said to have grown into a large company because of its innovation especially with the introduction of new and popular gluten-free breads and the introduction of milk dispensers that lower product price.

\section{The missing local contribution}

The common thread in diverse expressions of local knowledge is the recognition it can indeed add value to a largely Western-style R\&D script. They say Africa has unique problems whose solutions would somehow find their way to the international markets. A classic example is the innovation of Mpesa in Kenya, the peer-to-peer money transfer app for mobile phones that has found its way into the global market. Such innovation would never have happened in the Western world, owing to the fact that banks are accessible everywhere and the use of credit card is widespread. As such if Kenya had followed the Western script, the challenge of sending money to rural areas would still require a solution.

A number of survey respondents mentioned they had in the past tried to do things differently but always ended up in trouble because they departed from the 'norm' by not following the script. This thinking curtails creativity when the mindset of corporate leadership is such that some innovation is only good if it came from the West. This view emanates from the colonial past whose impact on the African entrepreneurial mindset has not been widely studied. The length of time colonial or pro-West mentality lingers depends on the entrepreneurial orientation (ability to take risk, proactiveness and innovative and independent thinking) of the African individual or company. The mindset change to think independently is occurring, however, as the example of the Tuskys Supermarket chain shows. Their affordable milk dispensers that in the absence of packaging materials saw the price of milk dropped by as much as $40 \%$.

The local knowledge input to innovation is critical to the survival of the enterprise, as has been demonstrated by the Tuskys case. Respondents cited many other cases where local knowledge has led to better product development. KCC, for example, through market research too has had to change the packaging of milk as a response to customer preferences. Multinationals 
operating in Kenya too have used local knowledge to bring new products. Sometimes, it is said that if you are able to make and sell a product in Africa, it can sell anywhere. This is in reference to the fact that when you manufacture in Africa, you may have to take into consideration price, functionality and the effective use case a little more effectively than in other parts of the world.

\section{Discussion}

The findings of this study and the earlier empirical review have indicated striking similarities, differences and new perspectives. African enterprises face similar growth paths to enterprises in other parts of the world, as explained by Rogers' [4] diffusion of innovation theory and Vernon's [5] concept of product life cycle. What are not envisaged in the trajectory of these two concepts are the behaviour patterns of two different markets. For example, whilst in the Western world landlines were in the late majority state in terms of innovation diffusion, Africa was getting up speed with the early adoption of technology. Demand for landlines was at fever pitch. So, it was natural for companies to leapfrog to mobile telephony. With some local knowledge inputs, Africa suddenly became a player within the innovation space in a fairly short period of time.

Of great concern is the hesitation common among business leaders to take risks in order to adapt and improve innovations. The entrepreneurial orientation in Africa is seemingly held back by a lack of confidence, a matter raised by Andah (1992). Africa may have fought for independence but not the systems it needs to take itself forward. The systems currently in place perpetuate dependence that moves from generation to generation that the effects of colonialism will be felt for centuries. Although it is virtually impossible to change systems within a short period of time, efforts should be made to start a process of mindset change to accommodate enhanced entrepreneurial orientation in Africa. It does not help that most of the products are imports or being produced under foreign script. There are far less new products created out of local input and the decision mechanisms that lead to new products are mostly decided elsewhere.

In a situation where ideas to make local products emanates from somewhere other than Africa, it will take longer to not only change the African mindset but also build the confidence to grow an enterprise that scales beyond the borders of Africa. In order to sustainably grow scalable enterprises, policymakers in Africa have to deliberately support local R\&D.

\section{Conclusion}

This paper and its accompanying research identified the convergence of four key areas that foster creativity and innovation and issues that undermine the same. These include enablers of creativity, opportunities that foster creativity and innovation, gaps that need to be filled and the challenges. In summary, there is great potential for Africa to exploit local knowledge that can contribute to global solutions. The sore thumb, however, is the lack of capacity to retain the 
human resource that is key to creativity and innovation. Hence, there is need to build research capacity through the development of $R \& D$ units as a strategy for greater creativity and innovation. There is dire need for governments to work closely with the private sector and the research institutions to provide research support to many MSMEs. The competitiveness of firms as well as countries of Africa depends on new innovations. Although Kenya has the institutional framework and the policies in place, there is need to work on human resource retention to stall the brain drain to high-paying countries of the developed world. The paper highlighted a number of gaps such as financing of $R \& D$ and failure to take the risk of incorporating local knowledge that if addressed would significantly impact individual firms that are held back by lack of these resources.

\section{Implications for policy theory and practice}

This research has significant implications for policy, theory and practice. Governments, especially from emerging countries, would immensely benefit from greater attention paid to the needs of entrepreneurs, their challenges, and so hopefully the recommendations this paper lays out. One of the aims of the study is to develop a new narrative around creativity and innovation in Africa that could be used to help organizations understand the approaches needed to develop effective R\&D units within their enterprises. Further, the findings are meant to provoke the research community, practitioners and policymakers into an informed discourse on creativity and innovation as a strategy for sustainable enterprise and economic growth.

Other objective of this paper is to identify how creativity and innovation can be supported in the African context, to establish the role of local knowledge around global innovation systems and how it can be incorporated into enhancing local R\&D capability for product development.

\section{Shortcomings of the study}

This was a qualitative research study with a very small number of firms participating. Hence, the study's findings may not readily be generalizable. There is need for more in-depth quantitative and large $\mathrm{N}$ research into the key areas identified in this study to realize more generalizable outcomes relevant to the African continent.

\section{Author details}

Bitange Ndemo* and Dennis Aiko

*Address all correspondence to: bndemo@uonbi.ac.ke

School of Business, Department of Business Administration, University of Nairobi, Nairobi, Kenya 


\section{References}

[1] Eghion, P., Blundell, R., Griffith, R., Howitt, P., Plantl, S. (2006). The Effects on Entry Incumbent Innovation and Productivity. Working Paper 12027, National Bureau of Economic Research, MA, USA.

[2] Amabile, T. (1988). 'A model of creativity and innovation in organizations', Research in Organizational Behavior, 10, 123-167.

[3] Mugabe, J.O. (2011). Science, Technology and Innovation in Africa's Regional Integration: From Rhetoric to Practice. ACODE Policy Research Series, 44.

[4] Rogers, E. (2003). Diffusion of Innovations, 5th Edition, Simon and Schuster. ISBN 978-07432-5823-4.

[5] Vernon, R. (1997). 'The Product Cycle Hypothesis in a New International Environment', Oxford Bulletin of Economics and Statistics, 41(4), 255-267.

[6] Aubert, J. (2004). Promoting Innovation in Developing Countries: A Conceptual Framework, World Bank Institute, Washington D.C.

[7] Baucus, M., Norton, Jr. W., Baucus, D., Human, S. (2008). 'Fostering Creativity and Innovation without Encouraging Unethical Behavior', Journal of Business Ethics 81, 97115.

[8] Davis, S.M., Meyer, C., Davis, S. (1999). Blur: The Speed of Change in the Connected Economy, Little Brown and Company, Boston.

[9] Waddock, S.A. (2001). Leading Corporate Citizens, McGraw-Hill Irwin, New York, NY.

[10] Kline, P., Saunders, B. (1993). Ten Steps to a Learning Organization, Great Ocean Publishers, Arlington, VA.

[11] Senge, P.M. (1990). The Fifth Discipline, Currency Doubleday, New York, NY.

[12] Kelley, T., Littman, J. (2001). The Art of Innovation: Lessons in Creativity from IDEO, America's Leading Design Firm, Currency \& Doubleday, New York, NY.

[13] Robinson, A.G., and Stern S., (1997). Corporate Creativity: How Innovation \& Improvement Actually Happen, Berrett- Koehler Publishers Inc., San Francisco, CA

[14] Gandz, J., Bird, F.G. (1996). 'The Ethics of Empowerment', Journal of Business Ethics, 15, 383-392.

[15] Thomke, S.H., (2003). Experimentation Matters: Unlocking the Potential of New Technologies for Innovation, Harvard Business Press. New York.

[16] Ndemo, E.B. (2015a). 'Political Entrepreneurialism: Reflections of a Civil Servant on the Role of Political Institutions in Technology Innovation and Diffusion in Kenya', Stability: International Journal of Security and Development, 4(1), 15, DOI: http://dx.doi.org/ 10.5334/sta.fd. 
[17] McCormick, D. (1999), 'African Enterprise Clusters and Industrialization: Theory and Reality', World Development, 27(9), 1531-1551.

[18] Nellis, J. (2005). The Evolution of Enterprise Reform in Africa: From State-owned Enterprises to Private Participation in Infrastructure - and Back? Center for Global Development, Washington, USA.

[19] Ndemo, E.B. (2015b). Effective Innovation Policies for Development: The Case of Kenya. The Global Innovation Index 2015. Effective Innovation Policies for Development.

[20] Allen, R.C. (2006). The British Industrial Revolution in Global Perspective: How Commerce Created The Industrial Revolution and Modern Economic Growth, Economic History Review, LVI, 403-443.

[21] Berg, M. (2005). Luxury \& Pleasure in Eighteenth Century Britain, Oxford University Press, Oxford.

[22] Mokyr, J. (1990). The Lever of Riches: Technological Creativity and Economic Progress, Oxford University Press, New York, NY.

[23] Crafts, N.F. (1977). Industrial Revolution in England and France: Some Thoughts on the Question: 'Why was England First? Economic History Review, 30, 429-441.

[24] Young, H. (1999). English Porcelain: 1745-95, V \& A Publications, London.

[25] Habakkuk, H.J. (1962). American and British Technology in the Nineteenth Century, Cambridge University Press, Cambridge.

[26] Baumol, W.J. (2007). The Return of the Invisible Men: the Microeconomic Value of Inventors and Entrepreneurs. Presented at the AEA meetings, Boston 2005.

[27] Andah, B.W. (1992). African Anthropology, Ibadan, Shaneson C.I. limited.

[28] Siyanbola, W.O., Egbetokun, A., Olamade, O., Helen, O., Sanni, M. (2012). Indigenous Technologies and Innovation in Nigeria: Opportunities for SMEs. American Journal of Industrial and Business Management, 2, 64-75.

[29] Mokyr, J. (2007). The Institutional Origins of the Industrial, Westview Press, pp. 1-127. Liège, Belgium.

[30] Bhagavan, M.R. (1978). A Critique Appropriate Technology for Underdeveloped Countries. Research Report No. 48. Journal of Scandinavian Institute of African Studies. No. 48 .

[31] Rogers, E. (2003). Diffusion of Innovations, 5th ed., Simon and Schuster, ISBN 978-0-74325823-4. Collier Macmillan, London.

[32] Yin, R.K. (2014). Case Study Research: Design and Methods, 5th ed., Sage, Los Angeles, CA. 
